\title{
Erratum to: Physiological basis of differential zinc and copper tolerance of Verbascum populations from metal-contaminated and uncontaminated areas
}

Filis Morina $^{1,4} \cdot$ Ljubinko Jovanović $^{2} \cdot$ Ljiljana Prokić $^{3} \cdot$ Sonja Veljović-Jovanović ${ }^{3}$.

J. Andrew C. Smith ${ }^{4}$

Published online: 11 April 2016

(C) Springer-Verlag Berlin Heidelberg 2016

Erratum to: Environ Sci Pollut Res

DOI 10.1007/s11356-016-6177-4

The list of co-authors was incomplete in the original article.

The complete Author list and affiliations are shown in this paper.

The online version of the original article can be found at http://dx.doi.org/ 10.1007/s11356-016-6177-4.

Filis Morina

filis@imsi.rs

1 Institute for Multidisciplinary Research, University of Belgrade, Kneza Viseslava 1, 11030 Belgrade, Serbia

2 Educons University, Vojvode Putnika 87, Sremska Kamenica, Serbia

3 Faculty of Agriculture, University of Belgrade, Nemanjina 6, Belgrade, Serbia

4 Department of Plant Sciences, University of Oxford, South Parks Road, Oxford OX1 3RB, UK 